\title{
Social Democratic Parties and Antitrust Policy: Evidence from Western Europe (2002-2013)
}

\author{
Mattia Guidi, Department of Political Science, LUISS Guido Carli, Rome
}

Yannis Karagiannis, Institut Barcelona d'Estudis Internacionals

[Accepted for publication on the European Political Science Review (April 2015)]

\begin{abstract}
This paper investigates the position of social-democratic parties (SDPs) towards antitrust (competition) policy. Given their traditional state-interventionist attitude and their ties with organized labour, SDPs have long been considered as not supportive of antitrust policy. However, antitrust policy's goal of granting consumers lower prices is beneficial to salary-earners. Hence, it is not surprising that SDPs' support for antitrust policy varies considerably. To account for such variation, this paper hypothesizes that SDPs' support for antitrust policy depends on: a) the influence of
\end{abstract}


trade unions; b) the electoral system; and c) the degree of coordination of the economy. Analysing in depth 16 party manifestos of West European SDPs from 2002 to 2013, we check the plausibility of our hypotheses with 7 paired comparisons. Our analysis supports the hypothesis that the influence of trade unions affects SDPs' support for antitrust policy, while the impact of electoral system and economic coordination appears less evident.

Keywords: antitrust; competition; party manifestos; social democracy; trade unions. 


\section{Introduction}

This article investigates the variation in European social-democratic parties' ('SDPs') commitment to enforce antitrust rules. SDPs are defined as all centre-left parties with an affiliation to the socialist international and/or the Party of European Socialists (see Cramme and Diamond, 2012; Giddens, 1998). "Antitrust rules" are the European equivalents of the Sherman, Clayton, and Federal Trade Commission Acts in the United States - i.e. rules prohibiting anti-competitive practices such as cartels, abuses of dominant positions in the market, mergers and acquisitions that may lessen competition. These rules, which are often seen as less intrusive than other forms of regulation, aim, among other things, at curbing abusive market power exercised individually or collectively by undertakings.

To gain an idea about the variation we investigate, contrast the British Labour Party's manifesto of 1997 with the Belgian Parti Socialiste's manifesto of 2003. The former proclaimed that "Competitiveness abroad must begin with competition at home", and that "[a]s an early priority we will reform Britain's competition law [... ] we will adopt a tough 'prohibitive' approach to deter anti-competition practices and abuses of market power"' 1 The latter declared that, "[a]gainst the market and its excesses, the PS wants to affirm the authority of the state. [...] Market regulation cannot possibly be limited to classical antitrust regulation.' ${ }^{2}$ So, why do some SDPs use their electoral manifestos to promise

\footnotetext{
${ }^{1}$ Similar pro-antitrust stances were adopted by the French Parti Socialiste in 2002, the Greek PASOK in 2007, and the Portuguese Partido Socialista in 2005 and 2009.

${ }^{2}$ Similarly sceptical stances can be found in the manifestos of the Italian Ulivo in 2006 (see also that of the Italian Partito Democratico in 2013) and the French Parti Socialiste in 2007, both of which focus more
} 
robust antitrust enforcement, while others prefer emphasizing the limits of antitrust, the necessity of "harder" regulation, or the need for industrial policies?

The question of whether SDPs should protect competitive markets or wait until the contradictions of capitalism render nationalizations and/or regulation necessary is, of course, as old as the debate between Kautsky and Bernstein (Sassoon, 1997). Yet it is also directly relevant to many current debates about the core values, the modernization, and the future of social democracy (e.g. Giddens, 1998: 35, 47, and 149-50; Kay, 2012: 68; Kenworthy, 2014: 104, 178; Powell, 2004; Sejersted, 2011). As most of these authors note, until recently SDPs had been associated with "egalitarian and redistributive values" (Powell, 2004: 6), and hence with planning, corporatism, and public spending (Giddens, 1998: 4; see also Boix 1998). Despite a few exceptions, they had never truly committed to the view that competitive markets yield the best possible allocation of resources, and that competition must therefore be protected. No wonder scholars wrote books about SDPs entitled "Politics against Markets" (Esping-Andersen, 1985) and "The Primacy of Politics" (Berman, 2005). As John Kay put it, "The European centre-left has not been very interested in the mechanics of markets" (Kay, 2012: 68). Although much of that has now changed, it has only partly done so. Since the 1980s SDPs have sought to "aid the market" (Thomson, 2000), often limiting themselves to proposing merely "light-touch regulation" (Kay, 2012: 63). Some scholars have even argued that the Anglo-Saxon antitrust regulation is "not exportable to Continental Europe" (Powell, 2004: 4; see also Meyer, 2007).

On the other hand, many theorists no longer perceive any contradiction between tradion regulation and industrial policy than on antitrust. 
tional SDPs' values and vigorous antitrust enforcement. According to a leading American social democrat, for example, a reliable antitrust regime is fully compatible with the goals of SDPs, because its aim is to avoid that "corporate behemoths" may "maintain market share and profitability despite little innovation" (Kenworthy, 2014: 104-5; see also Sassoon, 1997: 250; Amato, 1997; Monti, 2001). Also, regarding the purported incompatibility between antitrust and social democracy, scholars note that the German ordo-liberal tradition (Gerber, 1998) and the Scandinavian model (Kenworthy, 2014) have been able to reconcile the state-market dichotomy, safeguarding both economic competition and welfare state.

So, the literature is divided. However, if one sought to answer the question of whether antitrust is compatible with social democracy by looking at what SDPs actually promise in their manifestos, no straightforward answer would emerge. Even a cursory look at national SDP programmes reveals great variation. Such variation is visible even among parties whose countries are members of the Organization for Economic Cooperation and Development ('OECD'), the European Union ('EU'), and the European Economic Area ('EEA'). Within that group, noteworthy differences exist even among parties which are members of the International Socialist and the Party of European Socialists. Further, these differences do not seem to correspond either to differences in attitudes towards the process of European integration or to developments in EU competition law. The empirical puzzle we seek to address is thus the following: why do these parties, which are similar in so many respects, differ so much in terms of their sponsoring of antitrust policy as a solution to power-related market failures $?^{3}$

\footnotetext{
${ }^{3}$ We define cartels, monopolies and other types of dominant positions as "power-related market failures" in that they are self-defeating results of the market process which impede the working of the market,
} 
To answer that question we examine the plausibility of three different explanations which are all derived from a common rational institutionalist framework. First, the strength of the relations between the SDP and trade unions conditions the ability of party leaders to appeal to small businesses, and hence their ability to commit to pro-small business antitrust. Second, the proportionality of the electoral system creates more or less strong threats on a SDP's ideological left, and hence affects the political attractiveness of the policy. And third, the degree of coordination of the economy (i.e. the "variety of capitalism") defines how compatible antitrust is with other institutions, and hence makes it more or less politically attractive. Based on seven systematically selected comparisons and a wealth of triangulated primary and secondary sources, we conclude that the null hypothesis (a) can probably be rejected for the strength of trade union influence (i.e. the more a party depends on trade union support, the less it will support vigorous antitrust regulation); (b) might need to be considered in greater detail for the electoral system (i.e. SDPs in more proportional systems might be less inclined to propose strong antitrust measures); (c) can certainly not be rejected for the degree of coordination of the economy (i.e. the “variety of capitalism" does not seem to affect SDPs' positioning on antitrust).

These findings are relevant for at least three literatures. First, in comparative politics, they contribute to our deeper understanding of the variable nature of social democracy, including SDPs' electoral strategies and the profound impact of globalization and postmodernity on these parties. Whereas many interesting studies have explored the possibilities of social-democratic politics and policies in advanced industrial societies (e.g.

and which are due to the excessive market power that some undertakings or groups of undertakings might acquire. They are different from other kinds of market failures such as public goods, negative externalities, or limited information. 
Berman, 2006; Delwit, 2004; Kay, 2012; Kenworthy, 2014), none has done so by looking at antitrust policy as an instrument in the electoral toolkit of these parties. Second, in public policy in general, and the study of regulatory policies in particular, understanding when SDPs endorse antitrust regulation offers privileged insights into the nature of such ideologically ambivalent policies. Here the relevant debate is between those who interpret all market-based supply-side policies such as antitrust as essentially non-social democratic instruments (e.g. Esping-Andersen, 1985; Gerber, 1998; Meyer, 2007), and those who admit that at least some versions of antitrust are compatible with the broader ideological apparatus of social democracy (e.g. Amato, 1997; Crouch, 2012; Wigger and Nölke, 2007; Wilks, 1999). Third, a number of scholars have argued that governing coalitions delegate powers to non-majoritarian institutions in order to lock-in policies against future attacks by differently-minded governing coalitions (e.g. Moe, 1990; Gilardi, 2008; Thatcher, 2005). This thesis seems to be confirmed by the delegation of extensive powers by centre-right governments to independent antitrust regulators in such diverse countries as Austria (2005, popular party), France (1986, Gaullist party), Germany (1957, centreright coalition), Greece (1977, popular party), Norway (2005, centre-right coalition), or Sweden (2008, popular party). What remains to be seen, however, is whether SDPs truly pose a uniform and permanent threat to antitrust policies.

Below, Section 2 introduces an informal model of antitrust preferences of SDPs and proposes three main hypotheses. Section 3 offers some methodological comments regarding the operationalization of our variables, our sources of information, the qualitative case selection technique we follow, and the basis of our inferences. Section 4 presents our comparative case studies. Section 5 concludes. 


\section{Theory and hypotheses}

Historically, most SDPs represented the interests of the working class, defined as the nonasset owning segment of the population with a high propensity to spend. Accordingly, SDPs focused more on interventions to modify market outcomes and redistribute wealth, and less on hands-off, market-based mechanisms aimed at maximizing growth (Boix, 1998). Regarding structural microeconomic policies, nationalizations and/or hands-on regulation (i.e. not antitrust) are the kinds of solutions that are widely perceived as offering the best fit with SDP ideology. According to a legal historian, the support of SDPs for antitrust "has seldom been intense and committed [and] competition as a value does not fit easily with the rhetoric of left-oriented parties" (Gerber, 1998: 425).

Yet that is not conclusive evidence of the supposed incompatibility of SDP politics and antitrust ideology. Several SDP thinkers and politicians have been advocates of vigorous antitrust enforcement (Amato, 1997; Kenworthy, 2014; Giddens, 1999; Van Miert, 2001). As for parties, the British, French, German, and even Italian SDPs have often strongly supported new antitrust legislation. In 1948, Clement Attlee's Labour government passed Britain's first antitrust legislation. In 1989, the French socialist presidency of the EU did not veto, and perhaps even actively backed the first Merger Regulation. Other examples abound. Accordingly, in what follows we assume that vote-maximizing SDP leaders can choose whether to propose (or not) antitrust policy. Their choice depends on the costs and benefits of doing so.

Regarding the redistributive consequences of antitrust policy, consider a situation where technological advances render economies of scale, transaction costs, and barriers to entry increasingly important. Markets will concentrate, and cartels, tacit oligopolistic coordi- 
nation, long-term contracting, and monopoly power appear. Such a trend affects not only the public at large, but also the more competitively-structured sectors of the economy. If, as is most likely, private market power is not evenly distributed across nations, economic sectors and firms, political turmoil may occur - as it did in the 1880s America, or in the 1930s Germany. Further, the capture of the unevenly distributed monopolistic rents by a portion of the labour force will create inequalities. Although some workers (those employed in the relevant industries) will undoubtedly benefit, their gains will also contribute positively to the social costs of private monopoly (Weiss 1966). ${ }^{4}$ Finally, in so far as economic theory supports the view that increased competition at home is the best means to achieve higher rates of innovation and/or international competitiveness, politicians will have an incentive to protect and even foster domestic competition. Under these circumstances, SDPs may consider antitrust regulation.

On the other hand, if private market power can indeed lead to supra-normal profits, and if labour is organized, then the unions can capture a portion of monopolists' rents - the famous "monopoly wages" (Weiss 1966). This renders antitrust a politically less attractive option, particularly for parties which represent wage-earners.5 Indeed, monopoly wages are not just typically higher than competitive wages: provided that labour is unionized, they also bite into total employers' surplus, often at a level of more than $50 \%$ (Karier

${ }^{4}$ This result extends to all forms of private market power and not just unilateral monopoly; however, it does not extend to all forms of public market power, since the portion of rents that is not captured by labour is put to productive political use.

5 A preliminary assumption is that antitrust policy does not have the perverse effect of creating incentives for generous profit-sharing with unions in order to avoid antitrust detection under the profitability test. 
1985). It follows that anti-competitive markets (a) penalize most workers only a little, (b) benefit asset-owners to some extent, and (c) profit to a concentrated group of workers a lot. In addition, relatively bigger firms facilitate labour unionism because their workers face lower transaction costs at the moment of organizing and negotiating with managers, and have lower turnover rates. Moreover, even some small businesses may actually benefit from anti-competitive practices such as long-term contracting, accommodating price-fixing, or market-sharing agreements. Overall, this concentration of benefits, combined with the dispersal of costs, makes competition enforcement a politically risky option, particularly for SDPs.

With this in mind, we propose a theory of the political economy of SDPs' support for antitrust policy which rests on five reasonable assumptions. First, as far as this paper is concerned, policy options for the regulation of markets are essentially one-dimensional, and they go from outright nationalizations to complete laissez-faire. Between the two extremes, the choice that most SDPs face is that between the more interventionist ex ante regulation of markets and the more liberal antitrust enforcement.

Second, socio-economic actors view antitrust as instrumental in bringing prices closer to their competitive equilibrium level, and in improving the quality of goods and services. Competition compresses profits, and hence wages. Conversely, rent-seeking monopolies favour organized labour activities, and therefore consolidate the positive relationship between employer size and wages (e.g. Black and Strahan 2001, Brown and Medoff 1989).

Third, different socio-economic actors have different ideal points, which are common knowledge. The preferences of socio-economic actors are single-peaked decreasing functions of the distance between policy proposals and the agent's ideal point. First, trade 
unions represent working-class interests, which include both high wages and low prices (workers have comparatively low disposable incomes, and so prices affect them comparatively more). Yet, the mandate of trade unionists is biased in favour of job security, wages increases, and improvements in working conditions. It does not include bringing prices to their competitive level. Second, most small and medium-sized enterprises ('SMEs') and non-politicized consumers support vigorous antitrust. Even though some SMEs may benefit from restrictive price agreements, vertical price-fixing, and/or excessive monopolistic prices, on average they seek the protection of static competition. Conversely, firms with an important market share in a relevant product and geographic market on average benefit more from the absence of antitrust (Bittlingmayer 1992, McChesney and Shughart 1996). Finally, some SMEs and big capitalists favour industrial policy or laissez-faire.

Fourth, political parties tend to represent different socio-economic groups, but their preferences over non-constitutive, non-salient policies such as antitrust are those of officeseekers (vote-maximizers). Thus, SDPs' objective utility functions are flat within some distance around the ideal points of the groups they represent: within certain limits, their preferences are not totally exogenous to the balance of power between neighbouring socio-economic actors. $]^{6}$ Hence, within those limits, antitrust can be traded in exchange for votes and/or contributions.

${ }^{6}$ Communists prefer nationalizations and/or regulation; socialists prefer regulation and/or antitrust; liberals prefer antitrust; conservatives prefer antitrust and/or laissez-faire; and the far-right prefers laissezfaire and/or corporatism. Hence, the further away a political party is from the liberal "centre", the less it is likely to advocate a strong competition policy. For example, communist (state-monopolistic) and far-right (laissez-faire corporatist) parties are less likely to support antitrust than SDPs and Christian conservatives, who are in turn less likely to support antitrust than centrist parties. (Gerber 1998; for U.S. data, Gerring 1998) 
Fifth, SDPs' leaders seek to maximize electoral support (votes and/or campaign contributions which translate into votes). More specifically, SDPs represent predominantly salaried workers, but these are not a majority of the electorate. Therefore, SDPs face a trade-off: represent their core constituency by promoting particularistic policies (at the cost of acquiring an electoral majority), or make concessions to ideologically neighbouring constituencies (at the possible cost of alienating their core supporters) (Przeworski 1985). To sum up, antitrust is not constitutive of SDP identity: it is just not as central a concern to SDPs' core constituents as welfare, education, etc. In fact, most SDPs' core supporters should naturally favour slightly more heavy-handed regulation. But SDP leaders seek to gain voters, either on their left or on their right. This means they may attempt to use antitrust as a currency: they can promise more of it to centrist voters (SMEs), or less of it to leftist voters (trade unions). The question is, when will the balance tilt one way or the other?

In determining their electoral offer, SDP leaders consider the marginal rate of substitution between centrist (liberal, pro-antitrust) support by SMEs, and leftist (statist, anti-antitrust) support by trade unions. SDP leaders know that, if they promise vigorous antitrust enforcement, voters will interpret it as favouring lower prices, lower profits, and hence lower wages. This will appeal to SMEs, but it will alienate trade unions. If, on the other hand, SDP leaders promise permissive antitrust enforcement (e.g. direct regulation or even outright nationalizations), this will be interpreted as favouring higher prices, higher profits, and therefore higher wages. This attracts trade unions, but also alienates SMEs.

Now consider the case where unions are strong - i.e. where the unionization and concentration rates are high. To gain enough SME support to compensate for even a slight increase in competition (and hence a decline in financial, political, and moral support by 
trade unions), SDP leaders will have to promise policies close to the ideological centre. This is a high-risk strategy, because centrist and centre-right parties will react to attract their natural constituents (SMEs and consumers), thereby increasing these constituencies' elasticity of demand for SDP policies. Hence, in equilibrium, where unions are strong, the SDP party leadership should not promise a lot on antitrust. Conversely, of course, trade unions may be weak and split. Where that is the case, and therefore where SMEs/consumers are relatively stronger, to compensate for even a slight loss of competition, the concessions the SDP leadership would need to make to trade unions would need to be considerable. Hence, the party leadership will deem such a left turn non-worthwhile, and will promise a vigorous antitrust policy. Following this analysis, the crucial question becomes, what are the determinants of trade union power over the electoral strategy of an SDP? We propose a three-fold answer:

Firstly, and rather obviously, trade unions are strong when they can exercise control over the SDP leadership. Not only may the party rely on them for financial support, but they may also have the institutional to write the electoral manifesto, or to elect the party leadership and hold it accountable. A typical example of this would be the British Labour Party in the 1980s. In such cases it will be very risky for the SDP leadership to attempt to gain enough SME support to compensate for even a light increase in antitrust (and hence a partial loss of trade union support) - and vice versa. Hence, our first hypothesis is that: H1: The greater the influence of trade unions on an SDP, the less the party will promise on antitrust policy.

Second, trade unions are strong when there exists a credible leftist political alternative to the SDP. More specifically, the presence of an electorally strong communist, Green, or "old-left" party offers the unions a comfortable fallback position should they fall out 
with the SDP leaders, and hence increases the elasticity of their demand for policies. For example, where the electoral system and the distribution of voters' preferences allow for the presence of a potentially strong leftist party, trade unions will exhibit a very high elasticity of demand for antitrust policy. A typical example might be Italy, where the leadership of the Partito Democratico and its predecessors is sometimes constrained by the ability of the unions to back a potentially powerful leftist opposition. In such cases, the unions can desert the SDP faster than SMEs are able to join in support of it. Conversely, where the leftist opposition does not seem a credible electoral threat, the threat of trade unions will not be sub-game perfect, and therefore the SDP leadership will have more leeway to sponsor antitrust policy. Our second hypothesis is:

H2: The strongest the (potential) electoral threat on the left, the less an SDP party will promise on antitrust policy.

Third, trade unions are strong when the SDP leadership cannot easily champion policies which increase the party's appeal to the liberal centre. This is the case where the political economy of the country is characterized by strong coordination institutions (Hall and Soskice 2001). More analytically, economic policies usually exhibit a certain degree of complementarity (Boyer and Saillard 2001). A proposal for a policy change in some area must either be accompanied by a wider reformist agenda, or it will be perceived as cheap talk. Accordingly, a SDP proposal to reinforce antitrust enforcement will be more credible in a liberal than in a coordinated market economy - and vice versa. Therefore, our third hypothesis states that:

H3: The more coordinated a national political economy, the less the SDP will be able to credibly commit to more antitrust enforcement. 


\section{Methodological comments}

We are aware that statistical testing may yield accurate and generalizable results in the research on party manifestos. However, we find that existing databases of party manifestos do not properly distinguish between antitrust and other forms of regulation, and therefore suffer from problems of measurement error. Manifesto Project Database code 403, for example, yields the same score for quasi-sentences on antitrust (e.g. "cartels will be fined") and for traditional (i.e. anti-competitive) regulation (e.g. "utilities' prices will be capped"). Further, simple quantifications miss reputational issues. It is one thing to find that in 2005 the British Labour Party did not insist much on antitrust tout court, and quite another to acknowledge that by that time the party had already (a) proposed vigorous antitrust enforcement in 1997 and 2001; (b) passed the Competition Act 1998 and the Enterprise Act 2001; (c) worked towards convincing the sectoral regulators to apply antitrust law; and (d) been at the forefront of EU competition law modernization. Hence, having to choose between reliability and validity, we opt for the latter. We do so by conducting a series of controlled qualitative comparisons, where cases are selected on the basis of the variation of one independent variable at a time (King et al., 1994).

Regarding the use of electoral manifestos to derive the SDPs' stance on antitrust policy, we consider them as the most reliable and comparable source to gather information on the parties' policy formulation. We know that there can be relevant differences between what parties promise and what they actually do. Yet the research on manifestos is an important part of scientific studies on parties in general (see e.g. Budge et al. 2001, Klingemann et al. 2007) and specifically on SDPs (e.g. Wolinetz 1993, Volkens 2004). Moreover, considering different sources in our study would make the unit homogeneity assumption 
not tenable, and would make comparisons more arbitrary and difficult to interpret.

Regarding the operationalization of the variables, we take "union influence on an SDP" to be a function of not only the formal institutional rules that regulate the union-party relationship, but also of informal features which necessarily affect that relationship. For example, in 2000 the British and the Danish trade unions had roughly equivalent formal powers to influence their respective SDPs; yet Tony Blair's media-based politics made it so that the former had considerably less real influence than the latter. For Austria, Denmark, Greece, Ireland, Norway, Portugal, and Sweden - the cases we knew less well - we conducted two expert interviews per country. This yields the classification shown in the first column of Table 1 below.

To take a few examples, in Denmark union density has always been high, at around 74\%.7 Although 1995 marked the end of an era of very tight cooperation, the unions continued to finance the party until 2003. In Ireland, union density in the last twenty years has been around 45\%, and the Irish Congress of Trade Unions has been separate from the Labour Party since the 1930s. Nevertheless, the unions send delegates to the party's conferences, the election of the party's leader is often organized in the unions' headquarters, and the Services Industrial Professional and Technical Union and the municipal employees division of IMPACT trade unions, among others, are still affiliated to the party. In Germany, where union density is traditionally lower (about 26\% since 1990 on average) and where there is a long history of collaboration between the SDP and the main unions, that relationship was severely damaged by Gerhard Schröder's “Agenda 2010” and particularly

\footnotetext{
${ }^{7}$ Average value in the period 1980-2009. All data on unionization in the paper are taken from Visser
} (2011). 
the 2003 Hartz IV law on the reform of the labour market. At around 53\%, Belgium is a case of relatively high unionization; nevertheless, unions are split, and the one that is historically and ideologically closer to the country's two SDPs, FGTB/ABVV is only the second one in size. In France, union density is at only $8 \%$ (though the unions are still able to organize massive demonstrations), and most non-communist unions are jealous of their independence from political parties. In addition, relations between the Jospin government and unions with some affinity to the SDP (FO and CFDT) reached a historical low following the 2006 strikes against new employment contract for young workers.

Turning to the second independent variable, we only need to classify electoral systems from most majoritarian to most proportional. To do so, we have collected information from the ACE project at www.aceproject.org, and have cross-checked and interpreted that information using chapter 13 of the second edition of Principles of Comparative Politics (Roberts Clark et al. 2013). So, for example, the UK's Single-Member Plurality System places it at the majoritarian extreme, followed by France whose two-round majority runoff system for the presidential elections and its two-round majority plurality system for the ensuing general elections also create important anti-proportional effects. Austria's and Ireland's Hare systems place them at the proportional end of the spectrum.

As regards the degree of coordination, we rely on the indices of coordination in corporate governance and coordination in labour market calculated by Guardiancich and Guidi (2015), which are based on the same methodology used by Hall and Gingerich (2009). The corporate governance index measures how much firm control in a country is in the hands of common shareholders rather than held by a small number of them. The labour market index measures the power of unions in wage bargaining and the degree of its centralization (at state- rather than firm-level). Since the authors' data refer to the early 2000s, 
we integrated them with qualitative research for what concerns more recent years. So, for example, we follow Guardiancich and Guidi (2015) in considering Greece between 2000 and 2011 as a very coordinated economy, but we place it among the most liberal ones in the 2011-14 period, after the sovereign debt crisis and the subsequent surveillance of the "Troika" (International Monetary Fund, European Central Bank, European Commission). Similarly, we consider Germany as much less coordinated after the 2003 Hartz IV reform, compared to the years before.

\section{Influence of unions on SDP (highest to lowest)}

\section{Electoral system (most proportional to most majoritarian)}

\section{Coordination of the political economy (strongest to weakest)}

Denmark 2000-2003

Sweden

Norway

Austria 2000-2006

UK 2000-2003

UK 2011-2014

Ireland

Germany 2000-2003

Denmark 2003-2014

Austria 2006-2014

Belgium

UK 2004-2010

Germany 2003-2014

France 2012-2014

France 2000-2004

France 2005-2011

Spain

Greece

Portugal
Ireland

Austria

Norway

Sweden

Germany

Denmark

Belgium

Portugal

Spain

Greece

France

UK

\author{
Austria \\ Norway \\ Greece 2000-2011 \\ Belgium \\ Spain \\ Sweden 2000-2006 \\ Portugal 2000-2010 \\ Germany 2000-2004 \\ Denmark \\ Ireland \\ Portugal 2011-2014 \\ Greece 2011-2014 \\ Sweden 2007-2014 \\ France
}

Germany 2004-2014

UK

Tab. 1: Countries or SDPs classified according to their score on the three independent variables (2000-2014). 
As mentioned above, for the dependent variable we have avoided relying on premature quantification, and have opted instead for a purely qualitative approach. Accordingly, our operationalization focuses on the antitrust-related pronouncements of SDPs in their respective electoral programs in a specific election year. Electoral programmes were read from the beginning to the end, collecting all antitrust-related statements, including those that might only appear in specialized chapters (e.g. chapters on environmental protection, on agriculture, or on culture). To maximize validity, reliability, and communicability of our measurements and findings we base our case studies on extensive quotes from these texts, giving more weight to general (i.e. economy-wide) pronouncements and less weight to sector-specific ones.

The result is Table 1, which forms the basis of our case selection. Each column lists an independent variable, and a number of SDP electoral manifestos are ranked according to their score on that variable. All cases listed in Table 1 share a certain number of characteristics, which can therefore be deemed to be controlled for: advanced industrial democracy status (e.g. membership of OECD); EU/EEA membership; and SDP with experience of government. We have also limited the population by only considering cases between 2002 and 2013, thus controlling, among other things, for the secular decline of communism and the development of European antitrust and merger case law. In selecting cases for comparison we have also tried to take parties from equally-sized countries, thereby controlling for trade openness and thus the intensity of import-competition.

Finally, regarding our inferences, we rely on a combination of within-case assessment and the more usual correlational logic. The most important rule at this stage has been to examine the plausibility of different causal claims by privileging the null hypothesis. In the conclusion we come back to the issue of possible omitted variable bias. 


\section{Comparative case studies}

This section presents seven comparative case studies. For presentational reasons, we proceed to test the plausibility of our three hypotheses in reverse order. Hence, the first two comparisons assess the impact of the level of coordination of an economy; the third and fourth, the impact of the electoral system; and the fifth, sixth and seventh, the influence of trade unions.

\section{Comparison 1: Norwegian AP 2005 and 2009 vs. Swedish SAP 2006 and 2010}

These represent cases with roughly similar trade union influence (strong), near-identical electoral systems (very proportional), but different degrees of coordination of political economies (Norway more coordinated). H3 would be supported if the Swedish socialdemocratic party (Sveriges socialdemokratiska arbetareparti, SAP) proposed more antitrust than the Norwegian labour party (Arbeiderpartiet, AP) did.

Starting with SAP, it is the oldest, biggest, and most successful political party in Sweden. Its policies have reflected the interests of its core constituencies, namely blue-collar workers of umbrella trade union confederation Landsorganisationen i Sverige (LO), and public employees. It has been in favour of high welfare spending, a coordinated economy, and an important role for trade unions. After the loss of the 2006 general elections to the centre-right Alliance, the SAP formed an ephemeral alliance with the Greens and the Left. Despite the relaxation in the union/party links in 2003, some twenty national trade unions and LO are still rather influential in the party - though the second-biggest union 
confederation in Sweden (Tjänstemännens Centralorganisation) is not affiliated to any party. Unlike its Danish sister union, which cut its links to the social-democrats in 1995, the Swedish LO still supports SAP financially, runs the top-selling pro-SAP Aftonbladet daily newspaper, and nominates a member in the executive committee of the party. The party returns these favours by promoting the role of trade unions, including in its electoral manifestos, where it supports their role in signing comprehensive collective agreements and in managing globalization at the regional and global scales.

Turning to the value of the dependent variable, note preliminarily that Sweden is a country where all major modern antitrust laws have been passed under centre-right administrations, first in 1993 and then in 2008. In addition, the history of antitrust enforcement, both public and private, is rather short. To day only one cartel and one abuse-of-dominance cases have ended in condemnations. Against that background, it may not be surprising to find that, contrary to the centre-right Moderates, SAP did not make any promises in favour of antitrust enforcement either in its 2006 or in its 2010 manifesto. Although the absence of such promises in 2010 may seem to point to the influence of alliance with the Greens and the Left, the fact that the party had similarly not supported antitrust in 2006 seems to point to a more structural explanation, namely the influence of trade unions.

Turning to the Norwegian AP, like SAP it has traditionally been the largest and most successful party. Nevertheless, starting in the mid-1980s the party has entered a phase of relative decline. As a remedy, successive party leaderships since Gro Harlem Brundtland have adopted a more social-market economy profile, including promises for privatizations. In the end of the 1990s, AP finance minister and subsequently Prime Minister Jens Stoltenberg became nationally famous as an advocate of Tony Blair's New Labour ideology and policies. Regarding the links between AP and LO, the two organizations were 
formally separated in 1997 . Nevertheless, a weekly committee still coordinates the two leaderships' activities, the head of LO is elected to the AP leadership, and unions still finance the party. LO, which represents 21 national unions and counts more than 900,000 members, provides AP many of its star politicians - and vice versa (e.g. LO leaders Gerd-Liv Valla and Yngve Hägensen have held senior positions in AP).

Turning to AP's positioning on antitrust, it has been very similar to its Swedish counterpart's. Although the first modern antitrust legislation was passed in 1994 under an AP administration, since the turn of the century the centre-right seems to have acquired a monopoly over this policy. First, the new 2003/4 act was passed by the Bondevik admin-

istration. Second, the conservative Høyre party always calls in its manifestos for strong antitrust enforcement - for example, in 2005 they stated that "Høyre believes that it is the job of the government to facilitate competition through a strong competition law and the liberalization of public sector-dominated markets. [...] Høyre will prevent concentrations of power through appropriate legislation and strong and independent competition supervision." AP has never matched these proposals, insisting instead on the dangers of competition in finance, postal markets, and the utilities. So, contrarily to what we expected from $\mathrm{H} 3$, there do not seem to be notable differences between the SDPs of the two countries with respect to competition policy.

\section{Comparison 2: Austrian SPÖ 2006, 2008, 2013 vs. Irish LP 2007}

This comparison, too, aims at discovering the influence of the level of coordination of a national political economy on a SDP's ability to endorse antitrust policy. The cases score rather similarly regarding trade union influence on the party (medium), have near- 
identical electoral systems (very proportional), but differ regarding the degree of coordination of their political economies. H3 would be supported if the Irish Labour Party (LP) supported antitrust more than the Austrian social-democrats (Sozialdemokratische Partei Österreichs, SPÖ) did.

SPÖ is the oldest and one of the most successful parties in Austrian politics, though it has often had to rule in a grand coalition with the Christian democrats. Traditionally, it has advocated moderate centre-left policies. During the Cold War, the party fully endorsed Austria's neutrality policy. In the early 1980s, it briefly tried relying exclusively on its right wing (liberal) branch. Regarding its relationship with trade unions, it has to be noted that Austria has a peculiar union movement, whereby the Austrian Trade Union Federation (Österreichische Gewerkschaftsbund, ÖGB) is the only union, and the only workers' organization with the right to conduct collective bargaining. Thus, ÖGB represents more than one ideologically coherent movement - in fact, it is known for having factions which may support different political parties. Traditionally, of course, most ÖGB members and factions have supported SPÖ, and the union has provided the party with several highranking members. That close relationship was strengthened during the centre-right coalition government of 1999-2006, but it has since been loosened again. Now ÖGB insists it is non-partisan.

Regarding its positioning on antitrust, in 2006, 2008, and even 2013 SPÖ has always supported vigorous enforcement by independent institutions. In 2006, it insisted on making Europe more "social", and it was critical of the EU's predominantly liberal policies. It nevertheless advocated the liberalization of energy markets, proposed a competitive regime for the internet, and made a positive statement for antitrust. That policy became even more explicit in 2008, when it maintained its criticism of overtly liberal European 
policies, but also proposed to strengthen Austria's competition authority, and promised to step up the fight against monopolies - even proposing that in abuse of dominance cases the burden of proof lied with the accused. Finally, the 2013 manifesto reveals that SPÖ pro-antitrust positioning was no accident. SPÖ still proposed to strengthen the antitrust laws, increase the powers of the competition regulator, and act in energy markets.

Turning to Ireland in 2007, LP was never such a dominant force as AP, SAP, or even SPÖ, but still had several years of experience in government. The election was fought under the leadership of former eurocommunist politician Pat Rabbitte. Regarding unions/party links, they can be deemed roughly similar as those between ÖGB and SPÖ in Austria: although Labour and the Irish Congress of Trade Unions separated amicably in the 1930s, their relationship continues to be rather close, with debates for the election of the Labour leader often being held in union offices, and union delegates sent to Labour conferences. On the other hand, not all unions are affiliated to the LP, and relations have not always been smooth.

Regarding Labour's positioning on antitrust in 2007, it was rather ambiguous. In his forward to the manifesto Rabbitte did write that "it is the task of government to confront the arbitrary interests and the concentrations of power which hold people back." Similarly, in the main text Labour did promise to "adequately resource the competition authority to pursue rigorous competition enforcement". These relatively vague statements, however, are considerably shorter than the party's detailed plans on more hands-on regulation. At the very least, there is no evidence that LP was more pro-antitrust than was its Austrian counterpart. 


\section{Comparison 3: British Labour 2005 vs. German SPD 2009}

This comparison examines the possible influence of the electoral system. These cases represent parties in countries with similar degrees of political-economic coordination, similar levels of union influence on the party, but different electoral systems. H2 would be supported if British Labour proposed more antitrust than the German social-democrats' (Sozialdemokratische Partei Deutschlands, SPD) did.

Starting with the Labour Party, 2005 was the last election fought by (increasingly controversial) Tony Blair. The party still received support by trade unions, and the Trade Union \& Labour Party Liaison Organisation produced the 2004 Warwick Agreement just in time to allow the unions some influence on the party's manifesto. On the other hand, the widespread impression at the time was that Labour had become a middle-class, centrelooking party which did not rely on the unions for electoral victory.

Regarding Labour's positioning on antitrust, it declared that "competition is a driving force for innovation [and] our competition regime has been toughened with independent competition bodies and stronger penalties" and that "we will continue to work to protect the rights of consumers". That was a less enthusiastic endorsement of the policy than in the very pro-antitrust manifestos of 1997 and 2001. Yet, the difference may be due more to the achievement of the goals set in 1997 and 2001, rather than to the influence of trade unions. In conformity with $\mathrm{H} 2$ we thus interpret Labour's stance as pro-antitrust.

Turning to the SPD manifesto of 2009, it was written at a time when German trade unions showed exceptionally low levels of active support for SPD. Indeed, following Chancellor Gerhard Schröder's 2003 liberalizing and deregulating plan “Agenda 2010”, many unionists felt increasingly alienated, and many of them helped create the leftist party Die Linke. 
In line with this progressive detachment, the United Services Union (Vereinte Dienstleistungsgewerkschaft, VERDI) had taken over the traditionally pro-SPD metalworkers union IG Metall as the biggest member of the German Trade Union Confederation. All in all, the relationship between the unions and the party was roughly similar as that between the British trade unions and the Labour party in 2005.

The SPD's manifesto remained remarkably ambiguous on antitrust. On the one hand, it did briefly declare that SPD was "in favour of competition and antitrust policy", and it did state it would pursue an antitrust policy protecting small and medium-sized enterprises. On the other hand, it assured that fair competition should not be protected at the expense of wages and working conditions, and that "a new phase of cooperation, rather than just competition, must begin”. In coherence with that statement, the SPD promised to protect services of general economic interest, to regulate financial and energy markets, and to create "industrial policy opportunities". In conformity with $\mathrm{H} 2$, we interpret this as less pro-antitrust than the British Labour's stance.

\section{Comparison 4: French PS 2007 vs. German SPD 2009}

This comparison, too, examines the role of the electoral system, since in 2007 France and Germany were similarly liberal economies, and their SDPs were similarly distanced from trade unions. Since we examined the case of the German SPD above, we only need to present the French case here.

France is a country where most trade unions (except from former communist General Confederation of Labour, CGT) have long been jealous of their independence from political parties. Following decades of continuous decline, in 2007 unionization levels were 
at a mere $8 \%$, though unions maintained the ability to organize massive demonstrations. Despite some controversy over figures, the biggest union was CGT. In addition, since the Jospin government, which was regarded as too moderate in its economic policies, the PS had lost the active support of the unions, and even of its closest ally, the French Democratic Confederation of Labour.

In contrast with $\mathrm{H} 2$, which predicts that SDPs in less proportional systems should face less competition on the left and therefore be more in favour of antitrust enforcement, the PS did not promise anything on this issue in its 2007 manifesto. On the contrary, it declared that they "want to act like a real left-wing party ... against the marketisation [sic] of life" and against deregulation. It criticized EU competition policies in energy and water markets, and proposed an antirust exemption for services of general economic interests. Finally, the manifesto called for a new industrial policy.

\section{Comparison 5: Norwegian AP 2005, 2009 vs. Austrian SPÖ 2006, 2008, 2013}

This comparison examines the possible influence of trade unions. These cases represent parties in countries with similar degrees of political-economic coordination and very similar electoral systems, but different levels of union influence on the party. H1 would be supported if the Austrian SPÖ were more positive about antitrust than its Norwegian counterpart. The information in Comparisons 1 and 2 lends support to that view. 


\section{Comparison 6: German SPD 2002 vs. Spanish PSOE 2008}

This comparison examines the possible influence of trade unions. H1 would be supported if Spanish social democrats (Partido Socialista Obrero Español, PSOE) proposed more antitrust than the SPD did - which it did.

First, in 2002 the German SPD had not yet alienated unions the way it did with Gerhard Schröder's controversial Agenda 2010 speech on March 14, 2003. Further, traditionally pro-SPD union IG Metall was still Germany's largest union, VERDI not having formed yet. In its manifesto, the party backed structural reforms, and more competition in the rail market, but promised nothing specific on antitrust. That relative silence might be due to it having already passed new cutting-edge antitrust legislation in 1998. Nevertheless, the fact that Schröder had spent much of 2001/02 criticizing the European Commission's DG COMPETITION for failing to consider the needs of German industry (Smith 2005: 189) points to a purposeful decision to keep a decisively non-antitrust profile.

In Spain, like in France, non-communist unions do not maintain the kind of organic links

to SDPs that North European unions do. Despite the proximity between the General Union of Workers and the socialist party, relations are generally seen as severely damaged since the general strike of 1985 against the González administration. Combined with a low unionization rate (16\%), this allows PSOE more flexibility than the German SPD had in 2002 .

Regarding antitrust, PSOE's 2008 manifesto was very detailed and very supportive of the policy. Dedicating to it more than a page, it insisted on the compatibility of antitrust with egalitarian policy goals. Although it advocated more hands-on regulation for the labour, 
housing, finance, energy, and telecommunication markets, it highlighted the beneficial effects of vigorous antitrust enforcement in all other sectors. On the institutional side, PSOE promised to ease private enforcement, including class actions, and to reinforce the political and operational independence of the national competition authorities.

\section{Comparison 7: Belgian PS 2003, 2007 vs. Greek PASOK 2004}

Before 2009, Belgium and Greece were rather similar in terms of the degree of coordination of their political economies, and not too dissimilar in terms of their electoral system. However, they differed regarding the influence of trade unions on their respective SDPs. In Belgium, unionization was about 50\%. The General Federation of Belgian Labour, the second-largest trade union, maintained close relations with the socialist party (PS) (though it also had regular contacts with the Greens). Above all, it was considered by the PS as both a valuable electoral ally and a professional organization with valuable expertise. In Greece, on the other hand, unionization has long remained below 25\%. The two biggest trade unions, the Civil Servants' Confederation (ADEDY) and the General Confederation of Greek Workers (GSEE), have gone from a position of great subservience to the Panhellenic Socialist Movement (PASOK) in the 1980s and early 1990s to one where the party did not seem to need their support in the 2000s.

In conformity with H1, in both 2003 and 2007 the Belgian PS run on a considerably less pro-antitrust ticket than its Greek counterpart. For the PS, EU treaties must be amended to insert a social-policy goal for all policies, including the internal market and antitrust, for "market regulation cannot be limited to classical antitrust regulation". At the institutional level, "the state must guarantee the general interest [and] regulators must be autonomous 
and impartial but should not adopt policies which contradict those defined by the legitimate political authorities." In 2007, it noted that "even if competition has some positive effects, it also has some limits", which can be seen in the poor quality of utility provisions in Sweden and the UK. These statements contrast sharply with those of the centre-right Parti Réformateur, which took a decidedly pro-antitrust stance on both occasions.

As regards Greece, in 2004 PASOK promised to "adopt an effective regulatory framework that secures competition and consumer protection". After advocating the liberalization of regulated markets - including the professions - it defended its record on pro-competition privatizations, and promised a constitutional reform to create autonomous regulators, including an antitrust authority. Finally, it announced it would work towards empowering consumers' associations in their role of guardians of competition. This, too, confirms H1.

\section{Conclusions}

Based on the careful examination of fifteen SDP electoral manifestos and seven systematic comparisons, we have qualitatively tested three hypotheses about the determinants of SDPs' support for antitrust policy (see Table 2). We found preliminary evidence in support of our first hypothesis - namely, that a greater influence of trade unions on SDPs results in less pro-antitrust positions. The ten cases which go into our three comparisons on this dimension give preliminary support to the idea that the null hypothesis might be rejectable. If that is so, then unions may still have a way to influence policy - provided they are not evicted from the party.

Concerning $\mathrm{H} 2$, which hypothesized that a more proportional electoral system increases 
the chances of opposing antitrust policy, the evidence is more uncertain. Although one controlled comparison lent strong support to $\mathrm{H} 2$, the other did not. Given the centrality of this kind of institutional variables in the comparative politics literature (e.g. Chang et al., 2010), we believe that this is certainly an area where more theorizing and more empirical work are needed.

\begin{tabular}{cc} 
Hypotheses & Findings \\
\hline $\begin{array}{c}\text { H1: The greater the influence of trade unions on an SDP, } \\
\text { the less the party will promise on antitrust policy }\end{array}$ & Confirmed \\
\hline H2: The strongest the (potential) electoral threat on the left, \\
the less an SDP party will promise on antitrust policy & Mixed evidence \\
\hline $\begin{array}{l}\text { H3: The more coordinated a national political economy, the less the } \\
\text { SDP will be able to credibly commit to more antitrust enforcement }\end{array}$ & Not confirmed \\
\hline
\end{tabular}

Tab. 2: Summary of the main findings

Finally, as regards H3, the empirical analysis does not indicate any impact of the level of coordination of an economy on the positioning of a SDP on antitrust policy. The eight cases which inform our first two comparisons seem to show that "varieties of capitalism" do not matter. One interpretation of this result may be that Europeanization and globalization fritter away system-wide peculiarities.

Four steps may be taken in order to further explore this topic and define a political economy of antitrust. The first is testing the hypotheses derived from a more precise model with quantitative data. Particular attention should be devoted, in this case, to the operationalization of the dependent variable: how can 'support for antitrust' be measured in a consistent away across time and countries? How should mentions and non-mentions of antitrust policy be treated? Although such approaches have limitations, a time-series- 
cross-section dataset would have the advantage of letting us control for all possible explanatory and intervening variable in a much more accurate way. The second step to take involves analysing the evolution of SDPs' attitude towards antitrust through time. We know that SDPs have gradually come to embrace elements of (neo-)liberalism in their programmes (see Buch-Hansen and Wigger, 2011, for an overview), but how this has happened, and why it has happened earlier and more explicitly in some countries and not in others is an issue worth exploring. Third, it would be important to also go beyond manifestos, looking not only at what SDPs say, but also at what they $d o$. Is the variation we found in statements on anti-trust policy reflected in a different approach to competition legislation and enforcement? This is particularly interesting in the EU, where a common antitrust policy ties the hands of national governments. Are SDPs different from right-wing parties, and different from each other, when it comes to antitrust implementation? Finally, given that our research has highlighted the influence of trade unions on social-democratic parties in Europe, we think that a political economy of antitrust would strongly benefit from more specific knowledge of the attitudes of trade unions towards antitrust policy. Do they consistently advocate more hands-on regulation, or do they also support antitrust enforcement under certain conditions? These questions ultimately relate to the relationship between the European labour movement, which was born and prospered in the golden age of welfare state, and nowadays' globalized capitalism, which challenges the very existence of social democracy. 


\section{References}

Amato, G. (1997) Antitrust and the Bounds of Power: The Dilemma of Liberal Democracy in the History of the Market. Oxford: Hart Publishing.

Berman, E. (2006) The Primacy of Politics: Social Democracy and the Making of Europe's Twentieth Century. Cambridge, UK: Cambridge University Press.

Bittlingmayer, G. (1992) 'Stock Returns, Real Activity, and the Trust Question.' Journal of Finance, 47(5), 1701-30.

Black, S., and P. Strahan (2001) 'The Division of Spoils: Rent-Sharing and Discrimination in a Regulated Industry.' American Economic Review, 91(4): 814-31.

Boix, C. (1998) Political Parties, Growth and Equality: Conservative and Social Democratic Economic Strategies in the World Economy. Cambridge, UK: Cambridge University Press.

Boyer, R., and Y. Saillard (2001) Regulation Theory: the State of the Art. London: Routledge.

Brown, C., and J. Medoff (1989) 'The Employer Size - Wage Effect', NBER Working Paper No. 2870. http://www.nber.org/papers/w2870

Buch-Hansen, H. and A. Wigger (2011) The Politics of European Competition Regulation: A Critical Political Economy Perspective. London: Routledge.

Budge, I., Klingemann, H.-D., Volkens, A., Bara, J. and Tanenbaum, E. (2001) Mapping Policy Preferences: Estimates for Parties, Electors, and Governments, 1945-1998. Oxford; New York: Oxford University Press. 
Delwit, P. (2004) Où va la social-démocratie européenne? Débats, enjeux, perspectives. Brussels: Université de Bruxelles.

Doern, G. B., and S. Wilks (eds.) (1996) Comparative Competition Policy: National Institutions in a Global Market. Oxford: Clarendon Press.

Esping-Andersen, G. (1985) Politics against markets: The social democratic road to power. Princeton, N.J.: Princeton University Press.

Gerber, D. J. (1998) Law and competition in twentieth century Europe: protecting Prometheus. Oxford: New York: Clarendon Press; Oxford University Press.

Giddens, A. (1999) The Third Way: The Renewal of Social Democracy. Cambridge: Polity Press.

Gilardi, F. (2008) Delegation in the regulatory state: independent regulatory agencies in Western Europe. Cheltenham, UK; Northampton, MA: Edward Elgar.

Guardiancich, I. and M. Guidi (2015) 'The formal independence of regulatory agencies and Varieties of Capitalism: a case of institutional complementarity?' Regulation \& Governance (forthcoming).

Hall, P., and D. Gingerich (2009) 'Varieties of Capitalism and Institutional Complementarities in the Political Economy: An Empirical Analysis'. British Journal of Political Science, 39(3), 449-482.

Hall, P., and D. Soskice (eds.) (2001) Varieties of Capitalism. Oxford: Oxford University Press. 
Karier, T. (1985), 'Unions and Monopoly Profits.' Review of Economics and Statistics, 67(1): $34-42$.

Kay, J. (2012), 'The Mechanics of Markets: Politics, Economics, and Finance.' In O. Cramme and P. Diamond (eds.) After the Third Way. Cambridge, UK: Polity.

Kenworthy, L. (2014) Social Democratic America. Oxford; New York: Oxford University Press.

Klingemann, H.-D., Volkens, A., Bara, J., Budge, I. and McDonald, M. D. (2007) Mapping Policy Preferences II: Estimates for Parties, Electors and Governments in Central and Eastern Europe, European Union and OECD 1990-2003. Oxford; New York: Oxford University Press.

King, G., R. Keohane and S. Verba (1994) Designing Social Inquiry: Scientific Inference in Qualitative Research. Princeton, NJ: Princeton University Press.

McChesney, F., and W. Shughart (eds.) (1996) The Causes and Consequences of Antitrust: The Public-choice Perspective. Chicago: University of Chicago Press.

Meyer, T. (2007) The Theory of Social Democracy. Cambridge, UK; Malden, MA: Polity. Moe, T. M. (1990) 'Political Institutions: The Neglected Side of the Story.' Journal of Law, Economics, \& Organization, 6: 213-253.

Monti, M. (2001) 'Market definition as a cornerstone of EU Competition Policy'. Speech given at the Workshop on Market Definition - Helsinki Fair Centre, 5 October 2001. Retrieved from http://europa.eu/rapid/press-release_SPEECH-01-439_en.htm?locale=en 
Peritz, R. J. R. (1996) Competition Policy in America, 1888-1992 : History, Rhetoric, Law. Oxford University Press.

Powell, M. (2004) 'Social Democracy in Europe: Renewal or Retreat?' In G. Bonoli and M. Powell (eds.), Social Democratic Party Policies in Contemporary Europe. London: Routledge, pp. 1-20.

Przeworksi, A. (1985) Capitalism and Social Democracy. New York and Paris: Cambridge University Press and Maison des Sciences de l'Homme.

Sejersted, F. (2011) The Age of Social Democracy: Norway and Sweden in the Twentieth Century. Princeton, N.J.: Princeton University Press.

Sassoon, D. (Ed.) (1997) Looking Left: European Socialism After the Cold War. I.B. Taurus.

Thatcher, M. (2005) 'The Third Force? Independent Regulatory Agencies and Elected Politicians in Europe.' Governance, 18(3), 347-373.

Thomson, S. (2000) The Social Democratic Dilemma. Basingstoke: Palgrave Macmillan. Van Miert, K. (2001) Le marché et le pouvoir. Brussels: Racine.

Visser, J. (2011) ICTWSS: Database on Institutional Characteristics of Trade Unions, Wage Setting, State Intervention and Social Pacts in 34 countries between 1960 and 2007. Amsterdam Institute for Advanced Labour Studies (http://www.uva-aias.net/208).

Volkens, A. (2004) 'Policy changes of Europea Social Democrats, 1945-98'. In G. Bonoli and M. Powell (eds.) Social Democratic Party Policies in Contemporary Europe. London; New York: Routledge, pp. 21-42. 
Weiss, L. (1966), 'Concentration and Labor Earnings.' American Economic Review, 56(1): 96-117.

Wigger, A., and A. Nölke (2007) 'Enhanced Roles of Private Actors in EU Business Regulation and the Erosion of Rhenish Capitalism: the Case of Antitrust Enforcement.' JCMS: Journal of Common Market Studies, 45(2), 487-513.

Wilks, S. (1999) In the Public Interest: Competition Policy and the Monopolies and Mergers Commission. Manchester, UK: Manchester University Press.

Wolinetz, S. B. (1993) 'Reconstructing Dutch social democracy', West European Politics, 16(1), 97-111. 